ISSN 2455-1538

DOI: http://dx.doi.org/10.20431/2455-1538.0202001

www.arcjournals.org

\title{
In vitro Medicinal Studies on Ocimum gratissimum Leaves
}

\author{
Usunobun Usunomena, Uwadiae Eseosa \\ Department of Basic Sciences (Biochemistry unit), Faculty of Basic and Applied sciences, \\ Benson Idahosa University, P.M.B 1100, Benin City, Edo State, Nigeria. \\ uusunobun@biu.edu.ng, usunsquare@yahoo.com \\ Corresponding author: uusunobun@biu.edu.ng
}

\begin{abstract}
Background: Ocimum gratissimum known as 'scent leaf' is commonly used as spice in food and it is used also in traditional medicine practice for treatment of epilepsy, diarrhoea, mental illness and fever etc. The study was carried out to screen for phytochemicals, determine mineral constituents as well as show in vitro antioxidant potentials of Ocimum gratissimum leaves. Methods: Phytochemical screening, and mineral determination were carried out using standard procedures. DPPH free radical scavenging activity and reducing power activity were evaluated for their antioxidant activities. Results: Phytochemical screening revealed the presence of tannins, flavonoids, alkaloids, saponins, steroids and the absence of anthraquinones and glycosides while mineral analysis revealed the presence of sodium, calcium, potassium, manganese, copper, zinc, iron etc. in various concentrations. The result of reducing power activity and DPPH radical scavenging showed that, the higher the concentration, the better the scavenging activity. Conclusion: Our findings give credence to the use of Ocimum gratissimum in traditional medicine in the management of microbial infection and free radical induced ailments.
\end{abstract}

Keywords: DPPH, in vitro, Minerals, Phytochemicals, Ocimum gratissimum

\section{INTRODUCTION}

Ocimum gratissimum commonly known as 'scent leaf' is used In trado-medical practice, throughout West Africa as anti-malarial, antibacterial, antifugal, antiseptic, mosquito repellent and anticonvulsant [1]. Ocimum gratissimum is also used to treat different diseases including upper respiratory tract infections, diarrhea, headache, ophthalmic, skin diseases, pneumonia, and also as a treatment for cough, fever and conjunctivitis [2-3]. The aqueous leaf extract and seed oil showed antiproliferative and chemo-preventive activity on HeLa cells [4-5] reported that, aqueous extract of $O$. gratissimum leaves inhibits tumor growth and angiogenesis by affecting tumor cell proliferation, migration, morphogenesis, stromal apoptosis and induction of inducible cyclooxygenase (COX-2). In this study, we intend to analyze the phytochemicals, investigate the in vitro antioxidant activities and analyze the mineral components of Ocimum gratissimum

\section{Materials AND Methods}

\subsection{Collection, Identification and Preparation of Plant materials}

Fresh Ocimum gratissimum leaves were collected in January 2016 from a local farm in South Eastern part of Nigeria. Identification and authentication were carried out after which the leaves were sorted, washed and air dried at room temperature in Benson Idahosa University, Nigeria for fourteen (14) days. They were grounded into fine powder using an electric blender and stored in a cool dry container until use for analysis.

\section{Phytochemical analysis}

Qualitative phytochemical screening using standard methods as described [6-10] were carried out.

\section{Mineral analysis}

Mineral analysis was carried out using Atomic Absorption Spectrophotometer (AAS) as previously done [11-12]. 


\section{Determination of Reducing Power Ability}

The reducing power activity of Ocimum gratissimum leaves was carried out using the reducing power method as described by Aiyegoro and Okoh [13]. A mixture containing $2.5 \mathrm{ml}$ of $0.2 \mathrm{M}$ phosphate buffer (pH 6.6) and $2.5 \mathrm{ml}$ of $\mathrm{K}_{3} \mathrm{Fe}(\mathrm{CN})_{6}(1 \% \mathrm{w} / \mathrm{v})$ was added to $1.0 \mathrm{ml}$ of stock Ocimum gratissimum leaves filtrate $(0.2-1.0 \mathrm{mg} / \mathrm{ml})$ prepared in distilled water. The resulting mixture was incubated for 20 min at $50^{\circ} \mathrm{C}$, followed by the addition of $2.5 \mathrm{ml}$ of TCA $(10 \% \mathrm{w} / \mathrm{v})$, followed by centrifugation at $3000 \mathrm{rpm}$ for $10 \mathrm{~min} .2 .5 \mathrm{ml}$ of the supernatant was mixed with $2.5 \mathrm{ml}$ of distilled water and $0.5 \mathrm{ml}$ of $\mathrm{FeCl}_{3}(0.1 \% \mathrm{w} / \mathrm{v})$. The absorbance was measured at $700 \mathrm{~nm}$ against reagent blank sample. Increased absorbance of the reaction mixture indicates higher reducing power of Ocimum gratissimum leaves.

\section{2,2-Diphenyl-1-picrylhydrazyl (DPPH) radical scavenging ability}

The DPPH method according to Liyana-Pathiana and Shahidi [14] was used for the determination of DPPH free radical scavenging activity of the Ocimum gratissimum leaves as follows: DPPH $(1 \mathrm{ml}$, $0.135 \mathrm{mM}$ ) prepared in methanol was mixed with $1.0 \mathrm{ml}$ of stock Ocimum gratissimum leaves filtrate ranging in concentration from 0.2 to $1.0 \mathrm{mg} / \mathrm{ml}$. The reaction mixture was then vortexed thoroughly and left in the dark at room temperature for $30 \mathrm{~min}$. The absorbance was measured at $517 \mathrm{~nm}$. The scavenging ability was calculated using the equation: DPPH scavenging activity $(\%)=\left[\left(\mathrm{Abs}_{\mathrm{control}}-\right.\right.$ $\left.\left.\left.\mathrm{Abs}_{\text {sample }}\right)\right] /\left(\mathrm{Abs}_{\text {control }}\right)\right] \times 100$,

Where: $\mathrm{Abs}_{\text {control }}$ is the absorbance of DPPH + methanol and $\mathrm{Abs}_{\text {sample }}$ is the absorbance of DPPH radical + sample (sample or standard).

\section{Statistical analysis}

Data obtained from this study were expressed as mean value \pm standard deviation.

\section{RESUlTS AND DiscusSiON}

The phytochemical screening of ocimum gratissimum leaves showed the presence of various secondary metabolites including alkaloids, tannins, flavonoids, saponins etc as shown in Table 1.

Table 1. Phytochemical screening of ocimum gratissimum leaves

\begin{tabular}{|l|l|}
\hline Phytochemicals & Ocimum gratissimum \\
\hline Flavonoid & Present \\
\hline Saponin & Present \\
\hline Alkaloid & Present \\
\hline Tannin & Present \\
\hline Glycoside & Absent \\
\hline Anthraquinone & Absent \\
\hline Steroid & Present \\
\hline
\end{tabular}

The presence of tannins, saponins, flavonoids, alkaloids and steroids in Ocimum gratissimum leaves may contribute to antioxidant, anti inflammataory, analgesic, hypolipidaemic and antibacterial activity in in vivo studies. Flavonoids are polyphenolic compounds known to inhibit formation of plaques and streaks in arteries and so hinder hypertension, and other cardiovascular diseases [15-16]. They also are strong scavengers of reactive oxygen radicals known to be involved in many conditions that cause diabetes, inflammatory diseases, cancers and neurodegenerative diseases [17]. Tannins exerts many physiological effects, such as acceleration of blood clotting, reduction of blood pressure, decreasing the serum lipid level and modulating immunoresponses [18]. Saponins helps to lower cancer risks by lowering blood cholesterol levels. Alkaloids have a wide range of pharmacological activities including antimalarial (e.g. quinine), antiasthma (e.g. ephedrine), anticancer (e.g. homoharringtonine) [19], cholinomimetic (e.g. galantamine) [20], vasodilatory (e.g. vincamine), antiarrhythmic (e.g. quinidine), analgesic (e.g. morphine) [21], antibacterial (e.g. chelerythrine) [22], and antihyperglycemic activities (e.g. piperine) [23]. These phytochemicals may contribute analgesic, anti-pyretic, protective, antibacterial, anti-ulceration and ameliorating properties of ocimum gratissimum leaves. 
The result of mineral composition of Ocimum gratissimum leaves revealed calcium to be highest in concentration and Chromium least in concentration as shown in Table 2. Calcium plays role in coagulation of blood, proper heart and nervous system functioning and normal contraction of muscles. Calcium also aid formation of strong bones and teeth. Sodium and Potassium regulate the acid-base balance. Sodium remains one of the major electrolytes in the blood. Without sodium the body cannot be hydrated, it would dry up [24]. Iron is important for the building up of red blood cells essential for formation of haemoglobin, the oxygen carrying pigment in red blood cells. Iron is used against anaemia, tuberculosis and disorder of growth [25]. Zinc is very important for nerve function and male fertility. It is important for normal sexual development especially for the development of testes and ovaries. Zinc stimulates the activity of vitamins, formation of red and white corpuscles, healthy functioning of the heart and normal growth [26]. According to Burkhard et al [27], manganese is necessary for the functioning of the pituitary gland, the pineal gland the brain, it promotes hepatorenal function, combats anaemia and also essential for growth. Calcium content of Ocimum gratissimum (436mg/100g) is high compared to $295 \mathrm{mg} / 100 \mathrm{~g}$ of Celosia argentea [28] but low compared to $1118 \mathrm{mg} / 100 \mathrm{~g}$ of Annona muricata and $1264 \mathrm{mg} / 100 \mathrm{~g}$ of Vernonia amygdalina [11-12]. Zinc content of Ocimum gratissimum $(3.30 \mathrm{mg} / 100 \mathrm{~g}$ ) compared favorably to $5.42 \mathrm{mg} / 100 \mathrm{~g}$ of Celosia argentea [28] but high compared to $0.83 \mathrm{mg} / 100 \mathrm{~g}$ of Annona muricata and $1.42 \mathrm{mg} / 100 \mathrm{~g}$ of Vernonia amygdalina [11-12]. Sodium content of Ocimum gratissimum $(48.95 \mathrm{mg} / 100 \mathrm{mg})$ compared favorably with $48.31 \mathrm{mg} / 100 \mathrm{~g}$ of Vernonia amygdalina [12], but low compared to $69.49 \mathrm{mg} / 100 \mathrm{~g}$ of Annona muricata [11] and $71.32 \mathrm{mg} / 100 \mathrm{~g}$ of Celosia argentea [28]. Potassium content of Ocimum gratissimum $(109.60 \mathrm{mg} / 100 \mathrm{~g})$ is low compared to $128.33 \mathrm{mg} / 100 \mathrm{~g}$ of Celosia argentea [28] but high when compared to $36.31 \mathrm{mg} / 100 \mathrm{~g}$ of Annona muricata and $62.79 \mathrm{mg} / 100 \mathrm{~g}$ of Vernonia amygdalina [11-12]. Copper content of Ocimum gratissimum $(1.35 \mathrm{mg} / 100 \mathrm{mg})$ compared favorably with $1.95 \mathrm{mg} / 100 \mathrm{~g}$ of Vernonia amygdalina, $1.42 \mathrm{mg} / 100 \mathrm{~g}$ of Annona muricata [11-12] and $2.18 \mathrm{mg} / 100 \mathrm{~g}$ of Celosia argentea [28]. Iron content of Ocimum gratissimum $(9.48 \mathrm{mg} / 100 \mathrm{~g})$ compared favorably with $13.90 \mathrm{mg} / 100 \mathrm{~g}$ of Annona muricata but low compared to $32.20 \mathrm{mg} / 100 \mathrm{~g}$ of Vernonia amygdalina [1112] and $35.16 \mathrm{mg} / 100 \mathrm{~g}$ of Celosia argentea [28].

Table 2. Minerals present in Ocimum gratissimum leaves (mg/100g)

\begin{tabular}{|l|l|}
\hline Minerals & Ocimum gratissimum $(\mathrm{mg} / 100 \mathrm{~g})$ \\
\hline Calcium & $436 \pm 4.22$ \\
\hline Magnesium & $186.71 \pm 3.12$ \\
\hline Potassium & $109.60 \pm 3.09$ \\
\hline Sodium & $48.95 \pm 1.65$ \\
\hline Phosphate & $127.40 \pm 2.01$ \\
\hline Iron & $9.48 \pm 0.56$ \\
\hline Zinc & $3.30 \pm 0.26$ \\
\hline Copper & $1.35 \pm 0.20$ \\
\hline Manganese & $1.21 \pm 0.12$ \\
\hline Chromium & $0.89 \pm 0.10$ \\
\hline
\end{tabular}

Values are means \pm SD for 2 determinations

The result of reducing power activity of Ocimum gratissimum leaves showed a concentration dependent increase in reducing power ability as concentration increases from $0.2-1.0 \mathrm{mg} / \mathrm{ml}$ as revealed in Figure 1. The DPPH radical scavenging activity of Ocimum gratissimum is shown in Figure 2. The result revealed that the higher the concentration, the higher the percentage (\%) inhibition of DPPH radical. DPPH assay is commonly used for the assessment of free radicalscavenging abilities of herbal medicines and health foods due to their simplicity, stability, accuracy and reproducibility [29]. DPPH is a stable radical which can accept hydrogen from an antioxidant to form reduced DPPH [30]. From our results using reducing power and DPPH assays, Ocimum gratissimum leaves have strong abilities to react with free radicals and could convert them into more stable nonreactive forms that eventually lead radical chain reactions to termination. 


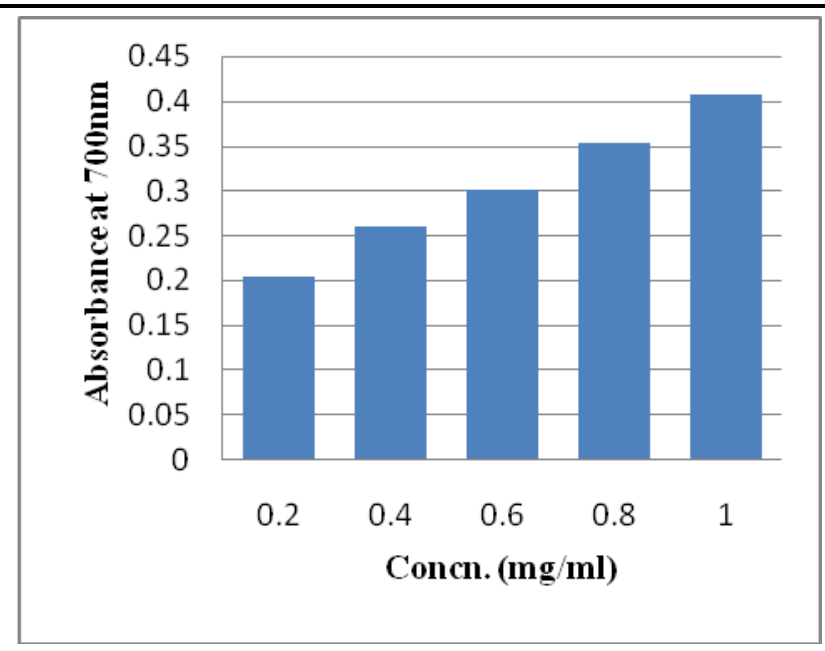

Figure 1. Reducing power ability of Ocimum gratissimum leaves

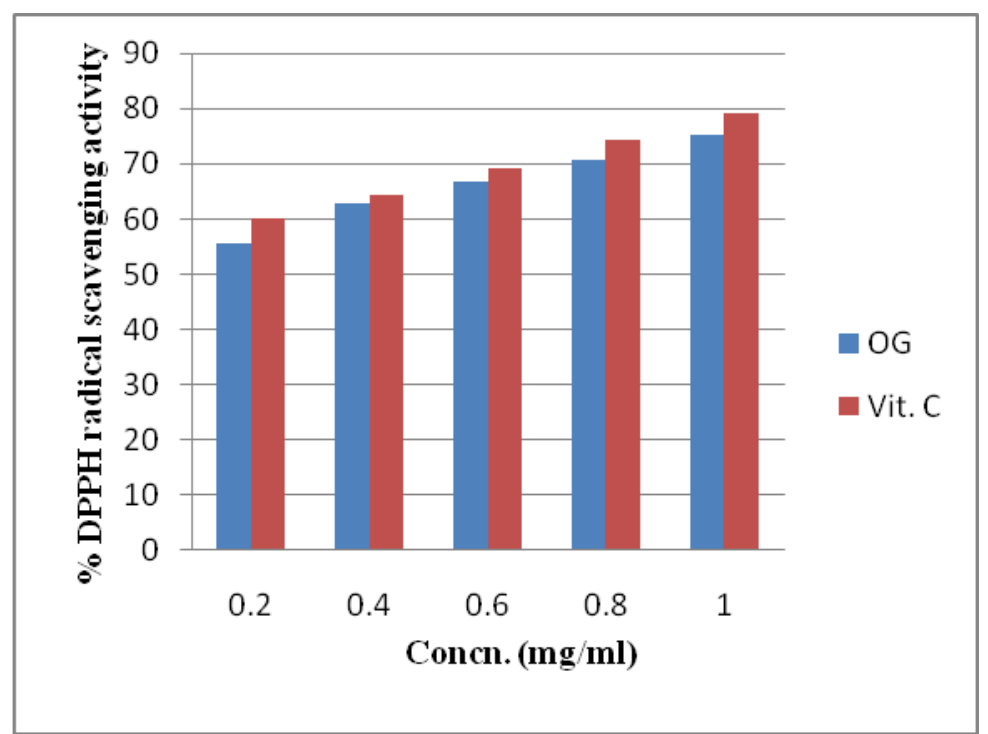

Figure 2. DPPH radical scavenging activity of Ocimum gratissimum (OG) leaves

\section{CONCLUSiON}

In conclusion, this study supports the rationale for the use of the Ocimum gratissimum leaves in treating infections in traditional medicine. Research should continue to isolate and purify active components of this plant and its use in experimental animals.

\section{REFERENCES}

[1] Ezekwesili C. N., Obiora K. A., and Ugwu O. P. Evaluation of antidiarrhoeal property of crude aqueous extract of Ocimum gratissimum in rats. Biokemistri. 16, 122-131 (2004)

[2] Ilori M., Sheteolu A. O., Omonibgehin E. A. and Adeneye A. A. Antidiarrhoeal activities of Ocimum gratissimum. J. Diarrh. Dis. Res. 14, 283-5 (1996).

[3] Onajobi F. D. Smoth muscle contracting lipidic soluble principles in chromatographic fractions of Ocimum gratissimum. J. Ethnopharma. 18, 3-11 (1986)

[4] Prakash J., Gupta S. K., Singh N., Kochupillai V., and Gupta Y. K. Antiproliferative and chemopreventive activity of Ocimum sanctum International J. Med., Biol. Env. 1, 165 (1999).

[5] Nangia-Makker P., Tait L., Shekhar M. P. V., Palomino E., Hogan V. and Piechocki M. P. Inhibition of breast tumor growth and angiogenesis by a medicinal herb: Ocimum gratissimum. Int. J. Cancer 121, 884-94 (2007).

[6] Sofowora L. A. Medicinal plants and Traditional Medicine in Africa. Spectrum Books Ltd, Ibadan, 1993. p. 55-71.

[7] Trease G. E and Evans W. C. Pharmacognosy 11th Ed., Tindall Ltd, London, 1985. p. 60-75. 
[8] Harbone J. B. Methods of extraction and isolation. In: Phy-tochemical Methods. Chapman and Hall, London (1998), Pp60-66.

[9] Usunobun U., Okolie N. P., Anyanwu O. G., Adegbegi A. J. and Egharevba M. E. Phytochemical screening and proximate composition of Annona muricata leaves. Euro. J. Bot., Plant Sci. Phytol. 2(1), 18-28 (2015).

[10] Usunobun U. and Okolie P. N. Phytochemical analysis and proximate composition of Vernonia amygdalina. Int. J. Scientif. World. 4 (1), 11-14 (2016).

[11] Usunobun U. and Okolie N. P. Phytochemical analysis and mineral composition of Annona muricata leaves. Int. J. Res. Curr. Dev. 1(1), 38-42 (2015).

[12] Usunobun U. and Okolie N.P. Phytochemical, trace and mineral composition of Vernonia amygdalina leaves. Int. J. Biol. Pharma. Res. 6(5), 393-399 (2015).

[13] Aiyegoro O. A and Okoh A. I. Preliminary phytochemical screening and in vitro antioxidant activities of the aqueous extract of Helichrysum longifolium DC. BMC Compl. Altern. Med. 10, 21-32 (2010).

[14] Liyana-Pathiana C. M. and Shahidi F. Antioxidant activity of commercial soft and hard wheat (Triticum aestivium L) as affected by gastric $\mathrm{pH}$ conditions. J. Agric. Food Chem. 53, 2433-40 (2005).

[15] Vaya J. and Aviram M. Nutritional antioxidants: mechanisms of action , analysis of activities and medical applications. Curr. Med. Chem. Immun., Endo. Metab. Agents. 1, 99117 (2001)

[16] Esterbauer H. and Puhl H. Effect of antioxidants on oxidative modification of low density lipoprotein (LDL). Ann. Internal Med. 23, 573- 81 (1991).

[17] Ugochukwu N. H., Babady N. F., Cobourne M. and Gasset S. R. The effect Gongronema latifolium extracts on serum lipid profile and oxidative stress in hepatocytes of diabetic rats. J. Biosci. 28(1), 1-5 (2003).

[18] Chung K., Wong T. Y., Wei C., Huang Y. and Lin, Y. Tannins and Human Health: A Review. Crit. Rev. Food Sci. Nutri. 38(6), 421-464 (1998)

[19] Kittakoop P., Mahidol C., and Ruchirawat S. Alkaloids as important scaffolds in therapeutic drugs for the treatments of cancer, tuberculosis, and smoking cessation. Curr. Topics in Med. Chem. 14(2), 239-252 (2014)

[20] Russo P., Frustaci A., Del Bufalo A., Fini M., and Cesario A. Multitarget drugs of plants origin acting on Alzheimer's disease. Curr. Med. Chem. 20(13), 1686-1693 (2013)

[21] Raymond S. S., Jonathan S. J. and Michael W. J. The Essence of Analgesia and Analgesics. Cambridge University Press. 2010. p.82-90.

[22] Cushnie T., Cushnie B. and Lamb A. Alkaloids: An overview of their antibacterial, antibioticenhancing and anti-virulence activities. Int. J. Antimicro. Agents. 44(5), 377-386 (2014)

[23] Qiu S., Sun H., Zhang A., Xu H., Yan G. and Han Y. Natural alkaloids: basic aspects, biological roles, and future perspectives. Chinese J. Nat.Med. 12(6), 401-406 (2014).

[24] Gbolahan D. Lesson Note on Medical Importance of Trace Elements. Centre for Natural Health Studies. 2001

[25] Claude B. and Paule S. The Manual of Natural Living. Edn 1, Biddles Ltd., Guildford, Surrey 1979. p. 98-101.

[26] Elizabeth K. Immense Help from Nature's Workshop. Edn 1, Elikaf Health Services Ltd. 1994. p. 207-209.

[27] Burkhard MJ, Brown DE, McGrath JP, Meador VP, Mayle DA, and Keaton MJ. Evaluation of the erythroid regenerative response in two different models of experimentally induced iron deficiency anaemia. Vet. Clin. Path. 30, 76-85 (2001).

[28] Usunobun U. and Ekpemupolo I. S. Phytochemical analysis, mineral composition and in vitro antioxidant activities of Celosia argentea leaves. Int. J. Scientif. World 4(1), 19-22 (2016).

[29] Vijaya K. R. C, Sreeramulu D., and Raghunath M. Antioxidant activity of fresh and dry fruits commonly consumed in India. Food Res. Int. 43, 285-288 (2010).

[30] Moon J. K and Shibamoto T. Antioxidant assays for plant and food component. J. Agric. Food Chem. 57, 1655-1666 (2009). 